\title{
Slovenia from the Austro-Hungarian Monarchy until nowadays: A brief historical overview
}

\author{
Egon Prijon ${ }^{1}$ \\ Lea Prijon, $\mathrm{PhD}^{2}$
}

The paper analyses the current Slovenian political and economic situation through interpretations of old socialist regime's modernisation. Right after the Yugoslavian disintegration, namely in the beginning of transition, the Slovenian starting position was the best, compared to other Yugoslavian countries and among other transitional countries. Between 1990/1991 and 2008 Slovenia seemed to be a politically more or less stable and economically well performing country. But after 2008 a negative trend hit the whole society, causing political instabilities and economic stagnation, reflected in negative macroeconomic indicators (i.e. GDP, GDP p.c. FDIs, unemployment, government debt, etc.). Could such a situation be explained on the basis of a long lasting socialist regime? If these suppositions are to be confirming, why do other transitional countries, which were subjected to a tougher communist regime, seem to be performing better nowadays?

Key words: Slovenia, socialism, communism, Yugoslavia, transition, modernisation, economy, politics

Predkladaný článok analýzuje súčasnú politickú a ekonomickú situáciu prostredníctvom interpretácie modernizácie nedemokratického socialistického režimu. Hned' po rozpade Juhoslávie a začiatku tranformáciu malo Slovinsko vel'mi pobrú pozíciu spomedzi ostatných bývalých štátov Juhoslávie. Medzi rokmi 1990/1991 a 2008 je možné konštatovat', že Slovinsko vykazovalo stabilnú pozíciu z pohl'adu politickej alebo ekonomickej výkonnosti. Avšak po roku 2008 negatívny trend zasiahol celú spoločnosti, ktorá vytvorali politickú nestabilitu a ekonomickú stagnáciu, reflektujúc smerom k makroekonomickým indikátorom (HDP, HDP v bežných cenách, ZPI, nezamestnanost', vládny dlh a pod.) Možno túto situáciu objasnit' prostredníctvom dlhovekého socialistického režimu? Ak sa však toto konštatovanie potvrdí, potom si musíme položit' otázku, prečo ostatné krajiny, ktoré boli v podobnej tranzícii vykazujú lepšiu výkonnost' v súčasnosti?

Key words: Slovinsko, socializmus, komunizmus, Juhoslávia, prechod, modernizácia, ekonomika, politika

1 CEO at Prijon Ltd., Žabji kraj 11, 5250 Solkan, Slovenia COO at Sapio Technical and Medicine Gases Ltd., Ul. Tolminskih puntarjev 12, 5000 Nova Gorica, Slovenia, E-mail: e.prijon@gmail.com

2 COO and CMO at Prijon Ltd., Žabji kraj 11, 5250 Solkan, Slovenia, E-mail: lea.prijon@ gmail.com. Assistant professor at the School of Advanced Social Studies, Gregorčičeva 9, 5000 Nova Gorica E-mail: lea.prijon@fuds.si 


\section{Briefly about Slovenia}

The purpose of our paper is to analyse the current Slovenian political and economic situation within the prospects of its historical events and modernisation. In fact, Slovenia was a part of the socialist (communist) regime for more than 70 years, which had (irreversible) consequences on Slovenian society. Slovenia was a part of the Austro-Hungarian Monarchy for more than 50 years, from which it inherited key elements, necessary for development in a (western) modern society. These elements seemed to be maintained over all political and economic crises, including World War I, the Great Depression, World War II, disintegration of Yugoslavia, and resulted in an excellent starting position in the beginning of transition in 1990. Nevertheless, they were not resistant to shocks and events after 2008.

Until the so-called Great Recession (i.e. the Global crisis), which began in the US in 2008 and spread over the world, Slovenia showed excellent results, i.e. a growing economy, political stability and social cohesion, which were on a stress test twice: the first time in the plebiscite on "Autonomy and independence" (in 1990), and the second time in the referendum on "Slovenia's accession to the EU and NATO" (in 2003). During these two events, the Slovenian nation and Slovenes showed a high cohesion by a high participation in the referendums and by a major share of votes ,for" independence, joining the EU and NATO. The Slovenian harmony was symbolically reflected as a common dream for a better future, and practically as an economic growth, progress and political stability. Thus, Slovenia started its transition in excellent economic and political conditions, unlike some other transition countries (e.g. Poland, the Czech Republic, Slovakia, or Hungary), which were in much worse conditions in the beginning of their transition and also for the years afterwards.

However, after 2008 the situation in Slovenia worsened, as political and economic troubles have emerged in the form of tycoon affairs, corruption, clientelism, political conflicts and economic recession. "A perfectly normal situation for a young democracy, which is still struggling for its existence and progress", one could say. However, if we consider the results of other, previously mentioned transition countries it seems that these are not in such a critical situation. Despite the fact that, according to some indicators (e.g. GDP p.c., unemployment rate, etc.), these countries are still doing worse than Slovenia, and it seems they are much more stable in their policies for solving the crisis.

Therefore, in this paper, we focus on the historical review of the Slovenian political and economic situation and modernisation, with the aim of interpreting nowadays' situation, which we perceive as a result of a continuous socialist (communist) tradition, which seems to have outweighed the efforts of transition in a democratic political system and free market economy. The socialist nostalgia slowly swept into 
the Slovenian society and, as it appears, deleted all negative experiences and memories from the last years of Yugoslavia's existence and malfunctioning. Perhaps, the reason for today's poor economic and political situation is to be attributed precisely to the fact that Slovenia performed within a less rigid socialist regime, unlike other transitional countries (like Poland, the Czech Republic, Slovakia, Hungary), which were subjected to a more rigid (Soviet) communism, which created and left feelings of resistance to such a system and the way of life.

\section{Between the Austro-Hungarian Times amd World War I.}

During 1867 and 1918, Slovenia was a part of the Austro-Hungarian Monarchy, which had a significant influence on its later developments in political, economic and cultural spheres, since Slovenia inherited crucial elements typical for Western societies. During this period, Slovenia underwent certain reforms, among which the most important ones concern the elimination of nobility's privileges and feudalism, which enabled the collapse of traditional institutions, thereby allowing the creation of basis for industrialisation and modernisation (see Adam, 1989).

After the 1857 depression, due to the collapse of Ohio Life Insurance \& Trust Co., which reached its peak in 1860, a political change occurred with introduction of the federalist "October Diploma", which triggered economic liberalism, accelerated industrialisation and urbanisation, whose important elements were the concentration of population in urban areas, immigrating from rural areas and deagrarisation, primarily due to economic reasons (Borak, 2002), which have led to modernisation in other social areas (political, economic, philosophical, etc.).

Modernisation in the 19th century decomposed the professional agrarian society, and thereby introduced crucial foundations of industrial society (Beck, 2001). Modernisation brought important changes in Slovenian society, which include progress in all areas, but the most successful and important one was in the political and social spheres. In fact, development of the Slovenian nation began precisely with modernisation in the entire spiritual structure and was manifested through the establishment of (Krek's) Christian Social Movement ${ }^{3}$, which had an impact on the economic and social stabilisation of migration (Kos, 1996).

In this time, handicrafts began to emerge (Mal, 1993; Božič, 1969), which represented the first beginnings of economic liberalism and competition and integration of artisans, which led in the common economic system. Towards the end of the 19th century, the flow of foreign capital intensified due to large joint-stock companies, while banks (with Czech, German and Hungarian capital) supported the Slovenian economic

3 Nevertheless, Krek's idea and visions further contributed to spreading of communism (Kos, 1996). 
development and industries. Savings banks, which had previously invested in industry, trade and crafts, became capitalist monetary institutions, which strengthened the formation of Slovenian bourgeoisie (Božič, 1969). In this sense, we could speak about the basis of economic liberalism, typical for western societies.

This period is called the "national movement", and it was marked by a number of new joint-stock enterprises, companies and banks that issued shares and thereby enabled a construction of new railways, factories, houses, etc. Crafts, which had been previously owned by foreigners, became Slovenian property. Craftsmen united in cooperatives, collaborating in terms of jointly buying raw materials, machines and building joint workshops (Mal, 1993; Brezigar, 1997).

Overall, economic prosperity was rising sharply since 1900 until World War $\mathrm{I}^{4}$ (Grdina, 2003), but it ended shortly after 1929 with the Great Depression. It started in the United States, later spread all over the world and brought about significant changes in the economic, political and cultural fields. Financial assets started to reduce, resulting in a serious financial crisis, which caused crumbling of enterprises and banks. Slovenia ${ }^{5}$ was severely affected by the Great Depression, as in its final stages it resulted in a total industrial paralysis, a decline in export trade in agricultural products, price drop and purchasing power of farmers, collapse of small businesses, fall of industrial prices, increased unemployment and poverty, etc. In addition, economic policies failed to solve the crisis' negative impacts, which caused the collapse of liberal capitalism. Such a situation disabled further development of liberal capitalism and also modernisation in the Slovenian society, as the latter was slowed down. Many small industrial enterprises and companies went bankrupt, while on the other hand, industry begun to concentrate in large cities, causing centralisation on the one hand, and deterioration of the suburbs on the other (Lazarević, 1997).

Such events enabled the communist party to take over power, starting to promote the idea of "classless society" through "anti-elite campaign", which disabled society's modernisation and urbanisation (Tomšič, 2006).

\section{Under the Communist Party Governance}

During World War II, all spheres of the Slovenian society were dominated by the Communist Party, characterised as a one-party system in the political sphere, and by rigid economy in the economic one. The principles of free economy like free market, private property and competition were unacceptable or even prohibited (Pezdir, 2008).

At this point, it is crucial to highlight that the Yugoslavian Communist Party is not

4 The economic situation in Central Europe begun to exacerbate already before World War I, and was further deteriorated by German pressures.

5 At that time, still a part of Yugoslavia. 
considered to be working on the basis of communist logic and principles, but rather on the socialist ones. Despite the fact that the Western world perceives and defines socialism and communism as the same regime, there are some crucial differences between them, which are especially relevant for countries that were a part of these two systems.

As stated, the differences between defining and understanding communism and socialism are blurred; nevertheless communism denotes the whole area of Eastern and Central Europe. Singer (2000) argues that the communist regime means an upgrade of the orthodox socialist orientation and the final stage of development to which individuals (should) aim. Heywood (2007) defines communism as a principle of common property, which is generally used for regimes and movements that are based on Marxist principles. Despite the fact that socialism was designed with the aim of creating a people's friendly and socially beneficial system (Heywood, 2007), Huerta de Soto (2010) defines it as a system based on institutional aggression and coercion on a free exercise of human will. Therefore, communism is to be considered as a repressive form of a political and social system, where democratic principles and human rights are suppressed. Nevertheless, they both, communism and socialism, can be considered as authoritarian regimes, which comprise institutional aggression, as defined by Huerta de Soto (2010). His definitions of socialism challenge the key idea of Western society (which implies stratification and social differentiation), as socialism promotes the idea of egalitarianism, anti-elitism, classless society, social ownership, the violation of basic human rights in terms of self-realisation, individualism, etc.

The latter could be observed in political (and economic) actions which have been carried out by political leaders (the Communist Party) immediately after 1945 when a "planned economy" was introduced, which had strongly negative consequences in a developmental context. The main aim of economic policy was focused on "selfsufficient economy", which resulted in a mixture of military and nationalistic economy (Pezdir, 2008). In 1947, the so-called "five-year economic plan" was introduced, developed on the basis of the Soviet model, whereby federal government and the federal planning commission set crucial guidelines for economic progress and policy, while central ministries were in charge of implementation of operational plans in specific sectors. In practice, this resulted in the planning of production, circulation and consumption of products (Slovenska kronika XX. stoletja, 1996).

Nevertheless, adverse internal and external conditions led to deviations from the plans, which were later replaced by "monthly experimentation" and "spontaneous problem solving" as a measure to prevent economic collapse (Slovenska kronika XX. stoletja, 1996). Since all these reforms were introduced and led by the federal government and the federal planning commission, the whole political system gradually started to dominate over the economic one and the whole society. Decisions regarding 
investments became the domain of state administration, while political institutions became the micro-enforcers of the state budget. Therefore, developments in the corporate sector depended on preferences of politicians responsible for economic policies (Pezdir, 2008).

In the 1950s, a new system called "socialist self-management" was introduced as a deviation from the then "centrally planned economy" (see Tomšič and Prijon 2012), which still contained certain key features of a communist economy, such as state control over the economy and the absence of private property. The economic market was subordinated to party leadership, it was centralised and resulted in monopolies. As five-year plans did not result in the expected objectives, a liberalisation of the Yugoslav (and thus also Slovenian) economy occurred (Pezdir, 2008) in the form of economic reforms, adopted in 1964 (Slovenska kronika XX. stoletja, 1996).

This reform ${ }^{6}$ was based on the economic sovereignty of all Yugoslav republics ${ }^{7}$ and their interconnection on the basis of common economic interests. The reform's logic comprised a combination of free market economy's principles, at the same time based on social ownership. Shortly after its adoption and implementation (1967), negative effects began to emerge (e.g. saturation of economy, accumulation of capital in foreign banks, etc.), which almost nullified the effects of reform in just a few years. A relatively high growth of the Slovenian economy resulted in a multi-annual economic stagnation (Slovenska kronika XX. stoletja, 1996).

\section{Approach to Yugoslavian Disintegration}

Between 1960 and 1970, the Yugoslav leadership was still focused on trials of society'smodernisation by introducing reforms that led to society's further fragmentation due to the lack of an appropriate institutional infrastructure and uneven distribution of goods and resources in economy and society in general (Grancelli, 1995). Such a "modernisation" also led to the fragmentation of technological structure, thereby undermining its key features and functions (e.g. technological process, production planning, quality control, long-term planning, etc.), which became bureaucratic again with re-introduction of traditional elements (Schierup, 1995).

Consequently, at the beginning of the 1970s, Slovenes had lived on the edge of development, which eventually awakened new "liberal flows", rising desires for liberation and modernisation of Slovenian society, politics and economy. Nevertheless, these were disabled by changes of local constitutions, blocking again Slovenian

6 Proposed by Edvard Kardelj.

7 The Socialist Republic of Bosnia and Herzegovina, the Socialist Republic of Croatia, the Socialist Republic of Macedonia, the Socialist Republic of Montenegro, the Socialist Republic of Serbia, the Socialist Republic of Slovenia. 
developments for a decade (Osolnik, 1998).

After the death of Kardelj (1979) and Josip Broz Tito (1980), the most powerful political figure in Yugoslavia, which tangled in transnational disputes in the last years of Tito's governance, Yugoslavia started to disintegrate. The economic and political crisis of self-management socialism started to deepen and disparities in economic balances were increasing. Therefore, experiments of "shock therapy" were introduced, which resulted in growing apathy of economy. Requirements for borrowing abroad increased, without a simultaneous control of finances and economic situation, which led to inflation accompanied with high armament costs of the Yugoslav Army. Slovenia, however, supported all economic reforms, as these were introduced with the aim of boosting productivity, personal initiative in economy, and market relations (Osolnik, 1998). However, these reforms did not lead to the improvement of the economic and general social situation; on the contrary, the crisis was growing.

For this reason, the International Monetary Fund demanded stabilisation measures, or repayment of the external debt in the amount of 7.4 billion $\$$, created during the government of Milka Planinc, who led the Yugoslav government between 1982 and 1986. The United States of America offered, in return for a stable and non-socialistical economy, restructuring of the national debt, but these offers were rejected by Planinc. Instead, she introduced the so-called "stabilisation measures", which were implemented as shock therapies ${ }^{8}$, resulting in a chaotic economy, growing country's debt, which led the hyperinflation to stagflation, and ended as a complete financial collapse and disintegration of the Socialist Federal Republic of Yugoslavia (M. Planinc "gurala", 2010).

As Slovenes had perceived the Yugoslav situation as worrying already before its collapse, desires for stabilisation of the whole society triggered many new social movements, which brought to light essential topics crucial, according to Inglehart (in Hafner-Fink, 2000), for post-modern values. These comprise quality of life, individualism, multiparty political system, concern for environment, spirituality, tolerance, etc. The new social movements strived towards modernisation of the Slovenian society in order to create a space for political pluralism, and hence to economic liberalism. Meanwhile, Slovenes' identity began to form, which can be understood as a response to an "incomplete and delayed" modernisation of the socialist society and as criticism of the traditional socialist (communist) elements. In addition, Slovenes began to see Western Europe as a "model of modern society", characterised by market economy, parliamentary democracy, the rule of law, etc. (Hafner-Fink, 2000).

8 These measures consisted of restrictions concerning imports of oil, limiting the consumption of electricity (called "reductions"), limiting departures abroad (to the west), a ban on imports of consumer goods, etc. 


\section{Secession and Independence the republic of Slovenia}

Shifts in cultural and symbolic spheres (Adam, 1989) were reflected in an idea of independence and a new economic and political system. The fact that the earlier described way of managing economic and political spheres started to bother Slovenians can be explained on the basis of its geographical position, as it is a part of Central Europe (Kundera, 1984). Therefore, Slovenia can be compared to the developed countries of Western Europe, due to western culture and Christian civilisation (Tomšič, 2002; Tomšič, 2008), despite the fact that its political system could be better associated with the eastern one (Kundera, 1984).

Wishes and interests of Slovenian nation's independence were first mentioned in the Volume 57 of Nova revija, while the informal political coalition presented a clear formulation of national interest, known as the Majniška deklaracija, in May 1989. The latter demanded a (social) order that would ensure spiritual and material welfare of Slovenian citizens, and thus became the conceptual foundation of a democratic coalition, called Demos (established in December 1989). Due to its programme based on moral principles, Demos committed to a peaceful transition from the authoritarian regime to a democratic society, whilst its policies and operations were not based on declarative anti-party revanchist. Demos strived for highlighting the truth about the past, to "repair" the injustices for denationalisation, de-ideologisation of school textbooks, and for national reconciliation, etc. (Prunk, 2002).

In December 1989, the Serbs attempted to organise the so-called "Meeting of the truth", which was successfully banned by Slovenian authorities. Afterwards, Serbia set up an economic blockade for Slovenia in the hope for a crisis to emerge, while it intervened in public finances and appropriated for 1.4 billion $\$$ from the common Yugoslav fund, which was the first step towards the Yugoslavian disintegration (Prunk 2002). Political parties, united as Demos, run in elections in April 1990 (Prunk, 2002) and won. Based on the plebiscite of "Autonomy and independence" on 23rd December 1990, Slovenia declared its independence on 26th June 1991 (for details see, Adam and Tomišič, 2012; Prijon, 2012a).

After Slovenia's independence from Yugoslavia, a transition process started to take place, at the beginning of which Slovenia had a much better starting position in comparison with other transition countries, e.g. Slovakia, the Czech Republic, Poland, etc. (for more on the Slovenian transition see e.g. Adam and Makarovič 2001, Adam and Tomišič 2012; Pezdir 2008; Prijon 2012a; 2012b; 2012c), due to its position in the Austro-Hungarian Monarchy and due to the fact that it was one of the (economically) most successful countries at the time of Yugoslavia.

After the collapse of the socialist system, a new socio-economic order has been

9 Samostojnost in neodvisnost 
created, while the systemic transformation of economy and other areas has been held under the gradualist model (see Pezdir 2008; Tomšic and Prijon 2012; Prijon and Tomšič 2012; Prijon 2012c). In the social area, transition comprised democratisation of political institutions, development of a democratic and effective government, development of a civil society and development of a new political culture as key institutions (for a more detailed description see e.g. Brezovšek 1998; Ferfila and Le Loup, 1999; Adam and Makarovič 2001) for successful transition in a new democratic regime.

The transition process ${ }^{10}$ started in $1989 / 90$, so its symbolic start is linked both with the collapse of communism and with the fall of the Berlin Wall. The transition comprises countries of Eastern and Central Europe and it means a transformation of traditional society into a modern one in all its spheres. Perhaps, the most important changes are linked with the changes in the political system (from communism/ socialism to democracy) and in the economic system (from centrally planned economy to a market oriented one). The transition also implies the establishment of democratic institutions, division of powers, freedom of speech, entrepreneurial initiatives, etc. (see Pezdir, 2008).

\section{Facts about Slovenia After Twenty-Three Years of its Independence}

When speaking about the transition in Slovenia, it is difficult to distinguish its course in the political and economic spheres, as both Slovenian politics and economy are (still) working hand in hand as a heritage from the previous socialist (communist) system. That is why the effects of the (gradualist) transition can be observed in a high rate of economic elite's reproduction recruited from politics, in a high number of economico-political interconnections, monopolies, stately owned enterprises, etc. The new post-communist country, i.e. independent Slovenia, continued to strive for creating a pluralistic party's politics and liberalisation of market economy in the first 10 years after the secession from Yugoslavia. Nevertheless, a trend of political polarisation occurred already before the end of the millennium. The central parties of the Slovenian government, which had successfully implemented all the necessary reforms from the beginning of the 1990s, changed from the liberal parties of the center-left parties, gradually evolving into the left and right parties, with aspirations to preserve the communist or the church's orientations. The effects of such a transition could be seen in the Slovenian political situation (presented in Table 1), where it can be observed that in the whole history of Slovenia as an independent state (from 1991) there was a coalition of the leftist parties which predominantly governed Slovenia.

10 Transition can occur in two different ways: gradualism or shock therapy (for more on the topic see e.g. Murrell, 1993; Hall and Elliott, 1999; Lipton and Sachs, 1990). 
Table 1: Slovenian governments between 1990 and 2012

\begin{tabular}{|c|c|c|c|c|}
\hline GOVERNMENT & PERIOD & $\begin{array}{l}\text { PRIME } \\
\text { MINISTER } \\
(\mathrm{PM})\end{array}$ & $\begin{array}{l}\text { PARTY AND } \\
\text { POLITICAL } \\
\text { ORIENTATI- } \\
\text { ON }\end{array}$ & $\begin{array}{l}\text { PERFOR- } \\
\text { MANCE OF } \\
\text { FUNCTION } \\
\text { AS A PM }\end{array}$ \\
\hline 1. Government RS & $\begin{array}{l}16.5 .1990- \\
14.5 .1992\end{array}$ & Lojze Peterle & $\begin{array}{l}\text { DEMOS } \\
\text { (right) }\end{array}$ & 2 years \\
\hline 2. Government RS & $\begin{array}{l}14.5 .1992- \\
25.1 .1993\end{array}$ & $\begin{array}{l}\text { Janez Drno- } \\
\text { všek }\end{array}$ & LDS (left) & 1 year \\
\hline 3. Government RS & $\begin{array}{l}25.1 .1993- \\
27.2 .1997\end{array}$ & $\begin{array}{l}\text { Janez Drno- } \\
\text { všek }\end{array}$ & LDS (left) & 4 years \\
\hline 4. Government RS & $\begin{array}{l}\text { 27.2.1997 - } \\
7.6 .2000\end{array}$ & $\begin{array}{l}\text { Janez Drno- } \\
\text { všek }\end{array}$ & LDS (left) & 3 years \\
\hline 5. Government RS & $\begin{array}{l}7.6 .2000- \\
30.11 .2000 \\
\end{array}$ & Andrej Bajuk & $\begin{array}{l}\text { SLS+SKD } \\
\text { (right) }\end{array}$ & 6 months \\
\hline 6. Government RS & $\begin{array}{l}30.11 .2000- \\
19.12 .2002\end{array}$ & $\begin{array}{l}\text { Janez Drno- } \\
\text { všek }\end{array}$ & LDS (left) & 2 years \\
\hline 7. Government RS & $\begin{array}{l}19.12 .2002- \\
3.12 .2004\end{array}$ & Anton Rop & LDS (left) & 2 years \\
\hline 8. Government RS & $\begin{array}{l}3.12 .2004- \\
21.11 .2008\end{array}$ & Janes Janša & SDS (right) & 4 years \\
\hline 9. Government RS & $\begin{array}{l}21.11 .2008- \\
10.2 .2012\end{array}$ & Borut Pahor & SD (left) & $\begin{array}{l}3 \text { years (unfi- } \\
\text { nished man- } \\
\text { date) }\end{array}$ \\
\hline 10. Government RS & $\begin{array}{l}10.2 .2012- \\
20.3 .2013\end{array}$ & Janes Janša & SDS (right) & $\begin{array}{l}1 \text { year (unfi- } \\
\text { nished man- } \\
\text { date) }\end{array}$ \\
\hline 11. Government RS & $\begin{array}{l}20.3 .2013- \\
18.9 .2014\end{array}$ & $\begin{array}{l}\text { Alenka Bra- } \\
\text { tušek }\end{array}$ & PS (left) & $\begin{array}{l}2 \text { years and } \\
6 \text { months } \\
\text { (unfinished } \\
\text { mandate) }\end{array}$ \\
\hline 12. Government RS & $\begin{array}{l}\text { 18.9.2014 - } \\
\text { current }\end{array}$ & Miro Cerar & $\begin{array}{l}\text { Party of Miro } \\
\text { Cerar (center) }\end{array}$ & Current \\
\hline
\end{tabular}

Source: Own table

Note: When Janez Drnovšek was elected president of Slovenia, Anotn Rop became Prime Minister.

Borut Pahor prematurely ended the function of Prime Minister after the motion. On December 4, 2011, the first early elections to the National Assembly of the Republic of Slovenia were took place. 
To sum it up, concerning the governance ratio in the whole 23 years of Slovenia's independence, there were 17 years of the left governance and only 6 years of the right one. The latter could be graphically demonstrated as drawn in the following Chart 1 .

\section{Chart 1: Graphical representation of Slovenian governments between 1990 and 2012}

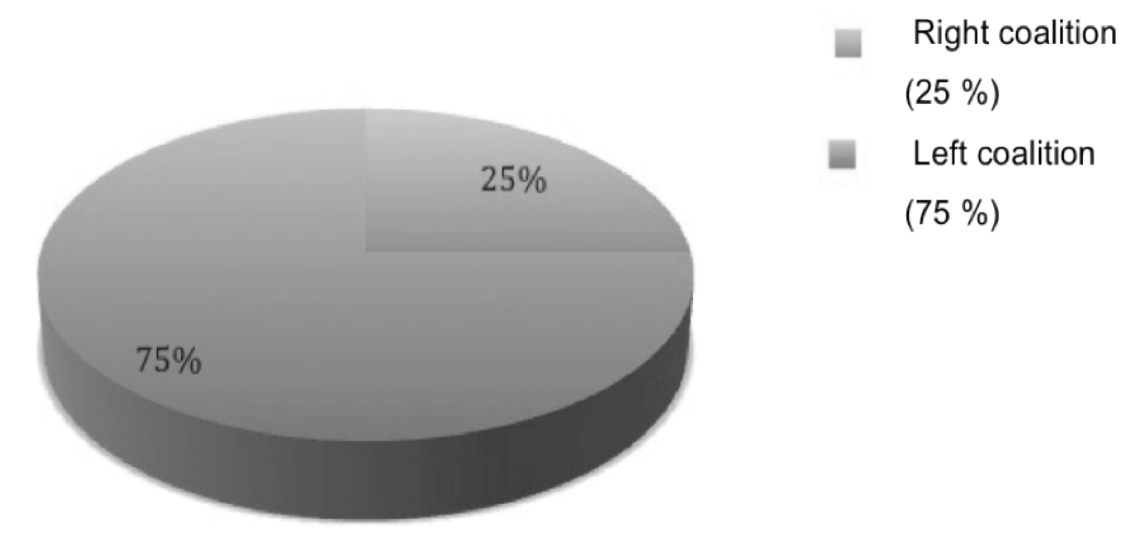

Source: Own design

Such a situation could be explained based on considerations that Slovenia is still lacking necessary components for a full transition to a western society. Considering Sztompka's (1993) claims that the result of the socialist tradition leads to the lack of market-oriented work ethic and the lack of democratic political culture, we could conclude that Slovenia surely fits these explanations. Further, Zver et al. (2005) claim that the transition countries still preserve pre-modern cultural trends which may affect the modernisation process, since these elements can act as counter-culture, representing a negation of the modernist or post-modernist culture. In this sense, this can result in rejection of democracy, adoption of the state control, legitimising of tax evasion, corruption, monopolism, etc. And, finally, we could use Tomšič's (2008) claims that the socialist regime has strongly influenced the way Slovenia has developed and it has affected its modernisation and social development, since they both found themselves in discontinuity, resulting in stagnation (Tomšič, 2008).

The facts that Slovenia was a part of Austro-Hungarian Monarchy and it had a much better starting position compared to the majority of other transition countries, have obviously lost their significance, as Slovenia's situation is becoming more and more serious, as reported also by the foreign media and institutions (like IMF, EBRD, etc.). In order to give an idea about the Slovenian situation, Table 2 provides a comparison of GDP and GDP (p.c.) in selected transition countries, i.e. Slovenia, the Czech Republic, 
Hungary, Poland, and Slovakia.

Table 2: Starting position of transition countries by GDP and GDP p.c. by year (in \$)

\begin{tabular}{|c|c|c|c|c|c|c|}
\hline & $\begin{array}{l}\text { SLOVE- } \\
\text { NIA }\end{array}$ & $\begin{array}{l}\text { CZECH RE- } \\
\text { PUBLIC }\end{array}$ & $\begin{array}{l}\text { HUNGA- } \\
\text { RY }\end{array}$ & POLAND & $\begin{array}{l}\text { SLOVA- } \\
\text { KIA }\end{array}$ \\
\hline \multirow[t]{2}{*}{1990} & GDP & $\begin{array}{l}17,381, \\
802,758\end{array}$ & $\begin{array}{l}34,879 \\
966,071\end{array}$ & $\begin{array}{l}33,056 \\
134,799\end{array}$ & $\begin{array}{l}64,549, \\
596,206\end{array}$ & $\begin{array}{l}11,716, \\
492,830\end{array}$ \\
\hline & $\begin{array}{l}\text { GDP } \\
\text { p.c. }\end{array}$ & 8,699 & 3,375 & 3,186 & 1,694 & 2,211 \\
\hline \multirow[t]{2}{*}{1995} & GDP & $\begin{array}{l}20,940 \\
864,809\end{array}$ & $\begin{array}{l}55,257, \\
045,968\end{array}$ & $\begin{array}{l}45,561, \\
413,231\end{array}$ & $\begin{array}{l}139,061, \\
765,458\end{array}$ & $\begin{array}{l}25,253, \\
597,386\end{array}$ \\
\hline & $\begin{array}{l}\text { GDP } \\
\text { p.c. }\end{array}$ & 10,524 & 5,351 & 4,411 & 3,603 & 4,710 \\
\hline \multirow[t]{2}{*}{2000} & GDP & $\begin{array}{l}\text { 19,979, } \\
467,790\end{array}$ & $\begin{array}{l}56,720 \\
835,331\end{array}$ & $\begin{array}{l}46,385 \\
589,534\end{array}$ & $\begin{array}{l}171,276 \\
118,424\end{array}$ & $\begin{array}{l}28,724, \\
041,828\end{array}$ \\
\hline & $\begin{array}{l}\text { GDP } \\
\text { p.c. }\end{array}$ & 10,045 & 5,522 & 4,543 & 4,454 & 5,330 \\
\hline \multirow[t]{2}{*}{2005} & GDP & $\begin{array}{l}35,717 \\
733,757\end{array}$ & $\begin{array}{l}124,548, \\
570,554\end{array}$ & $\begin{array}{l}110,321 \\
711,573\end{array}$ & $\begin{array}{l}303,912 \\
247,951\end{array}$ & $\begin{array}{l}61,328, \\
471,583\end{array}$ \\
\hline & $\begin{array}{l}\text { GDP } \\
\text { p.c. }\end{array}$ & 17,855 & 12,168 & 10,937 & 7,963 & 11,385 \\
\hline \multirow[t]{2}{*}{2010} & GDP & $\begin{array}{l}46,908, \\
328,072\end{array}$ & $\begin{array}{l}192,032, \\
097,602\end{array}$ & $\begin{array}{l}128,631 \\
634,125\end{array}$ & $\begin{array}{l}469,440 \\
132,670\end{array}$ & $\begin{array}{l}87,268, \\
098,543\end{array}$ \\
\hline & $\begin{array}{l}\text { GDP } \\
\text { p.c. }\end{array}$ & 22,893 & 18,254 & 12,863 & 12,294 & 16,071 \\
\hline
\end{tabular}

Source: Prijon, 2012a; 2012c (original data from The World Bank, 2012)

In the beginning of the transition (1990), Poland had the lowest share of GDP p.c., followed by Slovakia, Hungary and the Czech Republic, although these countries are much bigger then Slovenia. Notwithstanding, their GDP p.c. is still lower than Slovenian, but the gap between their initial and today's GDP p.c. is reducing. If Slovenian GDP p.c. increased by 2.6 times (from 1990 to 2010), Polish and Slovakian GDP p.c. increased by more than 7 times during the same period. From these data it can be deducted that Slovenia had been unsuccessful in its economic transition, which was further aggravated after the global economic crisis in 2008.

In situations like Slovenia is facing today, any economic growth cannot be expected, since the long-term economic policy of the country's governments is not consistent. They have behaved patronisingly, what was reflected, for example, in the publication of 
packages of developmental strategies, economic activities of governments, corruption, ignoring democratic elements of a liberalised market economy, the impact of policy and political preferences in the economic sphere, and so on, which is just the opposite to the logic of investing and of the liberal economic system itself.

Slovenian unsuccessfulness can be observed also in the field of foreign direct investments (see Table 3), as they are still the lowest (except Hungary) among the previously mentioned transition countries.

Table 3: Foreign direct investments (FDI) in the countries in transition (in \$)

\begin{tabular}{|l|l|l|l|l|l|}
\hline & 1990 & 1995 & 2000 & 2005 & 2010 \\
\hline $\begin{array}{l}\text { C Z E C H } \\
\text { REPUBLIC }\end{array}$ & n.d. * & 2,567, & 4,987, & 11,601, & 6,720, \\
& & 564,642 & 079,129 & 978,991 & 074,107 \\
\hline HUNGARY & 553,808, & 4,804, & 2,770, & 7,626, & $-42,283$, \\
& 992 & 151,332 & 479,254 & 151,047 & 449,518 \\
\hline POLAND & 89,000, & 3,659, & 9,343, & 10,309, & 9,104, \\
& 000 & 000,000 & 000,000 & 000,000 & 000,000 \\
\hline SLOVAKIA & n.d. $*$ & 236,132, & 2,052, & 2,411, & 553,142, \\
& & 979 & 480,853 & 132,115 & 912 \\
\hline SLOVENIA & n.d. $*$ & 150,400, & 135,800, & 540,400, & 366,161, \\
& & 000 & 000 & 000 & 963 \\
\hline
\end{tabular}

*n. d. $=$ No data

Source: The World Bank, 2012

Considering the comparison that The Economist (2012) gave in 2011 about the shares of FDIs in Ireland, Estonia, Cyprus, Slovakia, Portugal, Spain, Slovenia and Greece, where it is clearly visible that Slovenia's FDIs are almost the lowest (except Greece), it can be deducted that it had failed to implement a free market economy which should be based on international trading. 


\section{Chart 2: FDI inward stock in 2011 (\% of GDP) among countries}

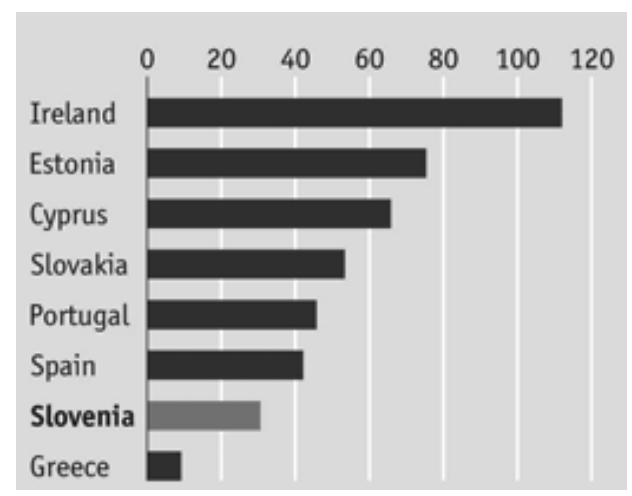

Source: UNCTAD in The Economist, 2012

The Bank of Slovenia lists potential reasons for such a small proportion of FDIs, which are similar to the explanations given by The World Bank (1999), i.e. a small Slovenian market, high and rigid bureaucracy, rejections of foreign investments, etc., which negatively affect Slovenian business and trading on the national and international bases (see Prijon and Tomšič, 2012). Future FDIs in Slovenia are yet more worrying due to its reluctant attitude to foreign capital and investors (Rojec and Kovač, 1999: 7).

Based on the latter, it can be concluded that investments, such as in the environment, will continue to stagnate, so it is almost impossible to make long-term forecasts for the economic progress, since it can be said that Slovenia is evaluated as an inappropriate environment for investments, as it has no basis for liberal market economy and, therefore it is quite unlikely to expect economic progress. In addition, investments in the last few years were made mostly in safer commercial establishments that are less capital intensive and risky for investors and thus have a lower rate of value added and income.

The further important economic factor is the rising trend in unemployment (measured by ILO), which has been growing since 2009. In Table 4 we present the data of five-year periods from 1998 to 2011, measured by the ILO methodology.

Table 4: Unemployment rate in Slovenia between 1998 and 2011

\begin{tabular}{|c|c|}
\hline YEAR & UNENPLOYMENT \\
\hline 1998 & $7,9 \%$ \\
\hline 2000 & $7 \%$ \\
\hline 2005 & $6,5 \%$ \\
\hline 2008 & $4,4 \%$ \\
\hline
\end{tabular}




\begin{tabular}{|c|c|}
\hline 2009 & $5,9 \%$ \\
\hline 2010 & $7,3 \%$ \\
\hline 2011 & $8,2 \%$ \\
\hline
\end{tabular}

Source: Vlada Republike Slovenije, 2013

Despite the fact that the unemployment rate had been quite high already in 1998 (7.9\%), it was falling and reached its lowest in 2008 (4.4\%). After the Global economic crisis (in 2009), the unemployment rate started to grow and almost doubled in 2011 $(8.2 \%)$. And even though it is still under the EU17 average (12.2\%), it has been rising faster compared to the EU average (Ignjatović, 2012). Indeed, according to the European Commission's (GMA/SS, 2013) arguments, Slovenia remains in recession precisely due to the high unemployment rate.

The Institute of Macroeconomic Analysis and Development (IMAD) argues that deterioration of the Slovenian labour market (compared to the EU) derives from a greater decline in its economic activity, which is the result of structural weaknesses of the economy of Slovenia. In addition, the long-term unemployment increased rapidly in Slovenia and it more than doubled in the period between 2008 and 2012 (Ekonomski izzivi, 2013).

In order to solve this problem, Slovenia adopted two intervention acts in 2009 which aimed at maintaining jobs, but these acts were only temporarily effective. After 2010, a further increase in the unemployment rate and a slightly more favourable system of unemployment benefits have strengthened the extent of the passive financial support of unemployed people (Ekonomski izzivi, ibid). But from the economic point of view, such measures are not the most appropriate policies, since a more proactive approach is needed to solve the increasing unemployment in the long run.

Finally, we submit the data concerning the central government debt, which is another worrying issue. In the following Table 5, we present the time span between 1995 and 2011 in order to highlight the situation in the beginning of the transition and after the economic crisis in 2008.

Table 5: Government's gross debt as percent of GDP

\begin{tabular}{|l|l|l|l|l|l|l|l|l|l|l|l|l|l|l|l|l|l|}
\hline Year & $\begin{array}{l}1995 \\
(1)\end{array}$ & $\begin{array}{l}1996 \\
(2)\end{array}$ & $\begin{array}{l}1997 \\
(3)\end{array}$ & $\begin{array}{l}1998 \\
(4)\end{array}$ & $\begin{array}{l}1999 \\
(5)\end{array}$ & $\begin{array}{l}2000 \\
(6)\end{array}$ & $\begin{array}{l}2001 \\
(7)\end{array}$ & $\begin{array}{l}2002 \\
(8)\end{array}$ & $\begin{array}{l}2003 \\
(9)\end{array}$ & $\begin{array}{l}2004 \\
(10)\end{array}$ & $\begin{array}{l}2005 \\
(11)\end{array}$ & $\begin{array}{l}2006 \\
(12)\end{array}$ & $\begin{array}{l}2007 \\
(13)\end{array}$ & $\begin{array}{l}2008 \\
(14)\end{array}$ & $\begin{array}{l}2009 \\
(15)\end{array}$ & $\begin{array}{l}2010 \\
(16)\end{array}$ & $\begin{array}{l}2011 \\
(17)\end{array}$ \\
\hline$\%$ & 18.6 & 21.9 & 22.4 & 23.1 & 24.1 & 26.3 & 26.5 & 27.8 & 27.2 & 27.3 & 26.7 & 26.4 & 23.1 & 21.9 & 35.3 & 38.8 & 47.6 \\
\hline
\end{tabular}

Source: Prijon and Pinterič, 2012 (original data from Statistical office of Republic of Slovenia: Government's deficit and debt

We present the same data in the following Chart 3 in order to give a better idea of the situation. 


\section{Chart 3: Government's gross debt (\% of GDP)}

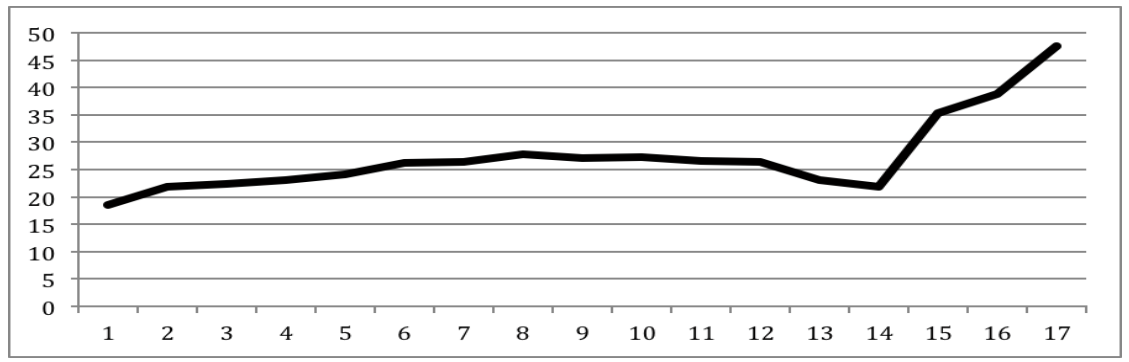

Source: Prijon and Pinterič, 2012 (original data from the Statistical office of the Republic of Slovenia)

Chart 3 shows that the gross debt fluctuated at around the same value between 1990 and 2007 (23\% - 27\%), and was the lowest in 2008. However, the Slovenian gross debt rose sharply immediately after the global crisis. Also considering the OECD and IMF calculations, the Slovenian central debt was sharply rising, as shown in the table below (Table 6).

Table 6: Total central government debt (\% of GDP)

\begin{tabular}{|l|l|l|}
\hline YEAR & $\begin{array}{l}\text { DEBT (in \% of GDP) - } \\
\text { OECD }\end{array}$ & $\begin{array}{l}\text { DEBT (in \% of GDP) - } \\
\text { IMF }\end{array}$ \\
\hline 2003 & $26,8 \%$ & $27,20 \%$ \\
\hline 2004 & $27,00 \%$ & $27,30 \%$ \\
\hline 2005 & $26,9 \%$ & $26,70 \%$ \\
\hline 2006 & $25,7 \%$ & $26,40 \%$ \\
\hline 2007 & $23,2 \%$ & $23,10 \%$ \\
\hline 2008 & $21,1 \%$ & $22,0 \%$ \\
\hline 2009 & $33,6 \%$ & $35,0 \%$ \\
\hline 2010 & $36,0 \%$ & $38,60 \%$ \\
\hline 2011 & n.d. & $46,90 \%$ \\
\hline $\mathbf{2 0 1 2}$ & n.d. & $\mathbf{5 4 , 1 0 \%}$ \\
\hline
\end{tabular}

Source: OECD, 2013

And even though the Slovenian debt is still under the EU-28 and EU-17averages (according to The European Commission (GMA/SS, 2013) it is still worrying to what extent it will rise and how it will be repaid. Capital leakage can also be an obvious consequence of the inefficient banking system that works under the supervision of informal networks. Due to the critical increase in the public debt (since 2008), we 
wonder whether it is a simple strategy to keep Slovenia's economy seemingly positive in order to make it appear economically focused, steady and attractive for foreign investors, at least at first glance.

Reassuming all data, we can claim that neither an economic recovery, nor a total solution of recession can be expected in Slovenia in a short time. In the years after the independence, Slovenian government adopted what we can call a "minimised variation of the Marshall Plan" for the economic start-up, with public works, privatisation, etc. The real outcome of such measures was granting privileges to individuals through public services, and an accelerated and uncontrolled privatisation, which led to managerial acquisitions, followed by emergence of tycoons, oligopolisation, centralised local economic operators, disabling or tampering with private enterprises, which further promoted and deepened the economic crisis.

And even though the Slovenian government(s) already adopted some measures after 2008 in order to restructure and improve the economic situation, Slovenia is still stuck in recession. The current situation is somehow similar to the one from the end of the 1980s, which is reflected in the economic situation (recession, a rising debt and borrowings, the malfunctioning economy, etc.) and in the political one (a rapid disintegration and changing of governments, conflict policies, etc.). The situation was similar just before Yugoslavia's disintegration, when (political) leaders led the economy in their own (political) interests. And even though today we do not speak about shock therapies or experiments, the logic of implementing and managing reforms is quite similar to the problem solving in Yugoslavia. The latter raises a question: Is a similar end that we already faced in 1990, i.e. a disintegration, to be expected?

The current Slovenian situation could also be explained in the context of different definitions of modernisation in the countries of Eastern and Central Europe. As for the modernisation process in these societies, authors use several expressions. Although Árnason (in Adam et al., 2001) speaks about the so-called "alternative modernisation" in communist societies, which was, despite the regime's rigidity, at the level of extensive industrialisation and urbanization and resulted in a relatively successful economic growth, this type of modernisation proved to be deformed and it cannot in any way "compete" with the same process in the developed western economy. Weber and Parsons already discussed this phenomenon at the end of the 1960s and later also Berger and other experts in this field did the same (Adam et al., 2001). The effects of the so-called "deformed modernisation" in the post- and real socialist systems can be observed in the underdevelopment of functional differentiation, but it is not the result of "politically and ideologically induced neo-traditionalism" itself, as it can also be explained in the context of a "particular culture" (cultural values, norms and traditions) of the socialist and communist systems. Cultural and civilisational factors can act as a driving force of modernisation and development, but they can also inhibit it at the same 
time (Adam, 1989: 23).

For interpreting a modernisation level of development, Ogburn (in Adam 1989: 24) introduced a concept of the "cultural lag", based on which we can clarify unsynchronised development of society's subsystems. The failure of modernisation or its deformed shape in socialist societies can be explained by a low desirability and traditional elements to which Yugoslavia was committed. However, these elements were facing innovations that accelerated modernisation in some segments. Modernisation was thus more intense in areas with better resources and conditions, which proved to be incapable of intensive, long-lasting and effective modernisation (Adam, 1989: 25-26).

\section{Conclusion}

Analyses of developments in the Slovenian society offer ambivalent findings, which suggest coexistence of two key moments. Despite the fact that Slovenia inherited some crucial elements of Western societies from the Austro-Hungarian Monarchy, its social development turned a different direction after World War II. The beginnings of a free market economy were formed in the mid-19th century with modernisation, industrialisation and urbanization as the basis for an industrial society. Nevertheless, the first key turning point occurred during World War I, when economic growth stalled, and the next one came in 1929 as a result of the Great Depression. A worsening economic (and political) situation continued until World War II and culminated when the Communist Party launched the so-called "planned economy". Despite the selfmanagement socialism and the ongoing reforms and measures to improve economy, the Socialist Federal Republic of Yugoslavia eventually disintegrated.

After the independence and post-communist transformation, i.e. transition, it seemed that good times finally came for Slovenia and Slovenes, as both the political and economic systems seemed to be changing. Although transition brought crucial changes and progress, it also neglected certain areas that urgently needed restructuring. As a result, today we still cannot clearly define what type of economic system Slovenia is functioning on, as some experts argue that it is still marked by traditional elements from the former socialist (communist) system. During transition, the so-called managerial capitalism enabled political individuals to merge political and economic areas, managed in accordance with their personal interests. The outcome of such a policy is preservation of their political links and levers in economy.

Today's political and economic situation of Slovenia certainly derives from historical events, when socialism (communism) ruled for such a long time, rejecting democracy and a free market economy, which would make the country more resistant to instabilities. Indeed, it is known that young democracies are more sensitive to changes and operate with more difficulties in turbulent times and environments. But, at this point, a reasonable question is: Why are most of other transition countries of 
Central and Eastern Europe more successful in their politico-economic situation than Slovenia? The answer to the question is certainly difficult and implies a number of possible interpretations, among others that Slovenia set poorly its objectives and the way to transition already in its beginnings.

\section{References}

ADAM, F.: Deformirana modernizacija: (Realni)socializem med tradicijo in modernostjo. Družboslovne razprave, vol. 6, no. 7, 1989, pp. 19 - 30 .

ADAM, F. - MAKAROVIČ, M.: Tranzicijske spremembe v luči družboslovnih analiz.Teorija in praksa, vol. 38, no. 3, 2001, pp. $373-385$.

ADAM, F. - MAKAROVIČ, M. - RONČEVIČ, B. - TOMŠIČ, M.: Sociokulturni dejavniki razvojne uspešnosti. Ljubljana: Fakulteta za družbene vede, 2001. 216 pp. ISBN: 961-6294$30-\mathrm{X}$

ADAM, F. - TOMŠIČ, M.: The Dynamics of Elites and the Type of Capitalism: Slovenian Exceptionalism? Historical Social Research, vol. 37, no. 2, 2012, pp. 53 - 90.

BECK, U.: Družba tveganja: Na poti v neko drugo moderno. Krtina: Ljubljana, 2001. 365 pp. ISBN: 978-961-260-042-6.

BORAK, N.: Ekonomski vidiki delovanja in razpada Jugoslavije. Ljubljana: Znanstveno in publicistično središče, 2002. 296 pp. ISBN: 961-6294-41-5.

BOŽIČ, B.: Zgodovina slovenskega naroda. Ljubljana: Prešernova Družba, 1969. 229 pp.

BREZIGAR, M.: Osnutek slovenskega narodnega gospodarstva. In: Borak, N. - Lazarević, Ž. - Prinčič, J. (eds.): Od kapitalizma do kapitalizma: Izbrane zamisli o razvoju slovenskega gospodarstva v XX. stoletju. Ljubljana: Cankarjeva založba, 1997. pp. 55 - 80.

BREZOVŠEK, M.: Cultura politica nella pubblica amministrazione Slovena. In: La pubblica amministrazione di frontea ll'Europa. Bologna: Societa editrice "Il Ponte Vecchio", 1998. pp. $21-35$.

Ekonomski izzivi 2013. Spremembe stanja in reforme na trgu dela v obdobju krize. Ljubljana: UMAR, 2013. Available at: http://www.umar.gov.si/fileadmin/user_upload/publikacije/ izzivi/2013/trgdela.pdf.

FERFILA, B. - LeLOUP, L. T.: Budgeting, Management and Policy Making: A Comparative Perspective. Ljubljana: Faculty of Social Sciences, 1999.572 pp. ISBN-10: 961-235-026-4.

GMA/SS. Spain, Slovenia face excessive problems with their economies: EU. Press TV, 10th April 2013 Available at: http://www.presstv.com/detail/2013/04/10/297556/spain-sloveniaface-severe-problems/.

GRANCELLI, B.: Who should learn what? In: Grancelli, B. (ed.): Social schange and modernisation. Lessons from Eastern Europe. Berlin: De Gruyter, 1995. pp. 3 - 42.

GRDINA, I.: Slovenci med tradicijo in perpsektivo: Politični mozaik 1860 - 1918. Ljubljana: Claritas, 2003. 386 pp. ISBN 961-6446-52-5.

HAFNER-FINK, M.: Slovensko približevanje Evropski uniji: Ideološki projekt ali proces (post)modernizacije. Teorija in praksa, vol. 37, no. 5, 2000, pp. 807 - 831.

HALL, T. W. - ELLIOTT, J. E.: Poland and Russia One Decade after Shock Therapy. Journal 
of Economic Issues, vol. 33, no. 2, 1999, pp. 305 - 314.

HEYWOOD, A.: Political ideologies: An introduction. Fourth edition. Palgrave Macmillan, 2007. 252 pp. ISBN 0-415-23677-0.

HUERTA De SOTO, J.: Socialism, Economic Calculation and Entrepreneurship (New Thinking in Political Economy). Massachutestts: Edward Elgar Publishing inc., 2010. 320 pp. ISBN13: 978-1849800655.

IGNJATOVIĆ, M.: EEO Review: Long-term unemployment, 2012. Slovenia. European Employment Observatory, 2013. Available at: www.eu-employment-observatory.net/.../ Slovenia-LTU-July2012.pdff.

KOS, J.: Duhovna zgodovina Slovencev. Ljubljana: Slovenska matica, 1996. 225 pp. ISBN 961-213-033-7.

KUNDERA, M.: Tragedija srednje Evrope. Nova revija, vol. 30, 1984, pp. 3456 - 3468.

LAZAREVIĆ, Ž.: V prvi jugoslovanski državi: Okolje, gospodarstvo in prevladujoče ideje. In: Borak, N. - Lazarević, Ž. - Prinčič, J. (eds.): Od kapitalizma do kapitalizma: Izbrane zamisli o razvoju slovenskega gospodarstva v XX. stoletju. Ljubljana: Cankarjeva založba, 1997. pp. $27-54$.

LIPTON, D., - SACHS, J.: Creating a Market Economy in Eastern Europe: The Case of Poland. Brookings Papers on Economic Activity, no. 1, 1990, pp. 75 - 147.

MAL, J.: Zgodovina slovenskega naroda: II. del. Celje: Mohorjeva družba, 1993. 1213 pp. ISBN 8675770979.

MURRELL, P.: What is Shock Therapy? What Did it Do in Poland and Russia? Post-Soviet Affairs, vol. 9, no. 2, 1993, pp. $111-140$.

M. Planinc "gurala" stabilizacijske ukrepe, a J. Kosor bije bitku s recesijom. Večerni List, 9th October, 2010. Available at: http://www.vecernji.hr/vijesti/m-planinc-gurala-stabilizaciju-aj-kosor-bije-bitku-recesijom-clanak-200992.

OECD - Organisation for Economic Co-operation and Development: Central Government Debt, 2013. Available at: http://stats.oecd.org/Index.aspx?DatasetCode=GOV_DEBT.

OSOLNIK, B.: O koreninah slovenske državnosti: Trnova pot mojega rodu. Novo mesto: Dolenjska založba, 1998. 218 pp. ISBN 961629704X.

PEZDIR, R.: Slovenska tranzicija od Kardelja do Tajkunov. Ljubljana: Časnik Finance, 2008. 158 pp. ISBN 978-961-6541-21-3.

PRIJON, L.: Efficiency of slovenian economic system since independence. In: Pinterič, U. Prijon, L. (eds.): Selected issues of modern democracy. Ljubljana: Vega, 2012a. pp. 167185.

PRIJON, L.: Power and position of Slovenian political and economic elite after transition: Who really rules Slovenia? Innovative issues and approaches in social sciences, vol. 5, no. 2, 2012 b, pp. $242-265$.

PRIJON, L.: Successfulness of Slovenian economic transition? Slovak Journal of Political Science, vol. 1, no. 3, 2012c, pp. $210-221$.

PRIJON, L. - PINTERIČ, U.: Public sector management in crisis: Disorientation case of Slovenia. In: Levi-jakšić, M. - Barjaktarović Rakočević S. (eds.): Innovative management $\&$ business performance. Belgrade: University of Belgrade, Faculty of Organisational Sciences, 2012. pp. $1600-1605$. 
PRIJON, L. -TOMŠIČ, M.: Business culture as a factor of international cooperation of Slovenian business sector. In: Besednjak Valič, T. - Modic, D. - Lamut, U. (eds.): Multifaceted nature of collaboration in contemporary world. London: Vega Press, 2012. pp. $381-417$.

PRUNK, J.: Slovenski nacionalni interes iz zgodovinske retrospektive. Teorija in praksa, vol. 39, no. 4, 2002, pp. 548-558.

ROJEC, M. - KOVAČ, M.: Spodbujanje neposrednih tujih investicij (NTI) v Slovenijo v pogojih članstva v Evrospki uniji. IB revija, no. 4, 1999, pp. $64-74$.

SCHIERUP, C.U.: Beyond Modernisation: The Retraditionalisation of Ex- and PostYugoslavian Society. In: Grancelli, B. (ed.): Social Change and Modernisation: Lessons from Eastern Europe. Berlin, New York: Walter de Gruyter, 1995. pp. 155 - 177.

SINGER, P.: Marx: A Very Short Introduction. New Edition. New York: Oxford University Press, 2000. 120 pp. ISBN-13: 978-0192854056.

Slovenia's economy: Next in line. Why yet another country may require a bail-out. The Economist 18th August, 2012: Available at: http://www.economist.com/node/21560567.

Slovenska korinika xx. stoletja: 1941 - 1995. Ljubljana: Nova Revija, 1996. 598 pp. ISBN: 961-6017-22-5.

SZTOMPKA, P.: Civilisational Incompetence: The trap of post-communist Societies. Zeitschrift fur Soziogie, vol. 2, no. 22, 1993, pp. 85 - 95.

The World Bank. Slovenia: Economic Transformation and EU Accession, Volume II: Main Report. The World Bank, Washington, D. C., 1999. Available at: http://www-wds. worldbank.org/external/default/WDSContentServer/WDSP/IB/1999/07/29/000094946_9 9041505302542/Rendered/PDF/multi_page.pdf.

The World Bank. 2012. Available at: http://data.worldbank.org.

TOMŠIČ, M.: Politična stabilnost v novih demokracijah. Ljubljana: Znanstevno in publicistično središče, 2002. 284 pp. ISBN: 961-6294-42-3.

TOMŠIČ, M.: Kulturne značilnosti slovenskih elit v luči evropskih integracijskih procesov. Družboslovne razprave, vol. 22, no. 51, 2006, pp. 73 - 91.

TOMŠIČ, M.: Elite v tranziciji. Nova Gorica: Fakulteta za uporabne družbene študije, 2008. 239 pp. ISBN: 978-961-6718-04-2.

TOMŠIČ, M. - PRIJON, L.: Slovenia. In: Ó Beacháin, D. - Sheridan, V. - Stan, S. (eds.): Life in post-communist Eastern Europe after EU membership: Happy ever after? London, New York: Routledge, 2012. pp. 95 - 114.

Vlada Republike Slovenije. 2013. Gospodarstvo. Available at: http://www.vlada.si/o_sloveniji/ gospodarstvo/.

ZVER, M. - ŽIVKO, T. - BOBEK, V.: Ekonomija in kultura: Umeščenost Slovenije v evropski ekonomskokulturni kontekst. Koper: Fakulteta za Management, 2005. 117 pp. ISBN 9616486942. 
Lea Prijon, PhD is an assistant professor at the School of Advanced Social Studies. In 2013, she successfully defended her doctoral thesis entitled: "Cultural profile of business-managerial elite", which dealt with macro and micro socio-cultural and socioeconomic factors/conditions for emergence of business-managerial elite, its cultural profile and role in society. Research topics: Slovenian economic processes during transition and nowadays, socio-economic conditions in comparative perspectives, economic and business elite.

Egon Prijon has a master degre in Business Informatics (2012) at the Faculty for Information Studies. A PhD candidate at the School of Advanced Social Studies, with doctorel thesis entitled: "Psycho-Social Genome". The aim of disertation is to develop a marketing tool, within the context of astrological sun signs (formally related to the natal chart horoscope) in order to be able to explain their consumer habits. Research topics: data mining and artificial intelligence, social media, cognitive psychology.

Egon Prijon

CEO at Prijon Ltd., Žabji kraj 11, 5250 Solkan, Slovenia COO at Sapio Technical and Medicine Gases Ltd., Ul. Tolminskih puntarjev 12, 5000 Nova Gorica, Slovenia, E-mail: e.prijon@gmail.com

Lea Prijon, $\mathrm{PhD}$ COO and CMO at Prijon Ltd., Žabji kraj 11, 5250 Solkan, Slovenia, E-mail: lea. prijon@gmail.com. Assistant professor at the School of Advanced Social Studies, Gregorčičeva 9, 5000 Nova Gorica, E-mail: lea.prijon@fuds.si 